\title{
Bottle Conditioning: Technology and Mechanisms Applied in Refermented Beers
}

\author{
Kateřina Štulíková ${ }^{1,2, *}$, Jan Novák ${ }^{2}$, Jakub Vlček ${ }^{1,3}$, Jan Šavel ${ }^{3}$, Petr Košin ${ }^{3}$ \\ and Pavel Dostálek ${ }^{1}$ D \\ 1 Department of Biotechnology, Faculty of Food and Biochemical Technology, University of Chemistry and \\ Technology, Technická 5, 16628 Prague, Czech Republic; jakub.vlcek@budvar.cz (J.V.); \\ pavel.dostalek@vscht.cz (P.D.) \\ 2 Lonza Biotec s.r.o., Okružní 134, 28161 Kouřim, Czech Republic; jan.novak@lonza.com \\ 3 Budějovický Budvar, N.C., 37004 České Budějovice, Czech Republic; jan.savel@budvar.cz (J.Š.); \\ petr.kosin@budvar.cz (P.K.) \\ * Correspondence: stulikoa@vscht.cz
}

Received: 29 July 2020; Accepted: 3 September 2020; Published: 9 September 2020

\begin{abstract}
Bottle conditioning refers to a method of adding fermenting wort or yeast suspension in sugar solution into beer in its final package. Additionally denoted as bottle refermentation, this technique has been originally developed to assure beer carbonation, and has further significance related to formation of distinctive sensory attributes and enhancement of sensory stability, which are the phenomena associated with ongoing yeast metabolic activities in the final package. This review covers historical development of the method, describes metabolic pathways applied during refermentation, and explains practical aspects of the refermentation process management. Furthermore, an overview of the traditional and novel approaches of bottle conditioning with mixed yeast bacterial cultures and its impact on the properties of final beer is provided.
\end{abstract}

Keywords: bottle conditioning; refermentation; kräusening; bioflavoring; brewing yeast

\section{Introduction}

The brewing industry has undergone a global transformation as a result of the ongoing craft beer revolution, associated with an increasing number of craft beer producers who have flooded the market with innovative and intriguing beer styles using novel ingredients and production methods to attract consumer interest and provide a unique sensory experience [1,2]. From customers' point of view, biological generation of flavors and use of natural ingredients appears more attractive, and therefore this approach has become a strategy of choice for beer producers as it increases the probability of the acceptance of their product on the market [3]. The induction of new flavors into beer or alteration of existing flavors by addition of new ingredients or fermenting microorganisms that are connected with the relevant technological adjustments in the brewing process is termed bioflavoring. Bottle conditioning, which can be considered as a type of bioflavoring, is a traditional method developed in order to enhance beer carbonation. Bottle conditioning, also denoted as bottle refermentation or bottle kräusening, indicates an additional fermentation in the bottle that is initiated by adding yeast and fermentable carbohydrates [4]. During the saturation phase, in the first 14 days of refermentation, as a result of yeast multiplication, alcohol concentration, and carbonation increases and the concentration of various flavor-active compounds are altered, which results in changes of beer aroma and taste [5]. Due to the yeast's reducing properties and consumption of oxygen present in the final package, bottle conditioning can prevent oxidative damage, which is successively manifested by aging of beer and development of stale flavor. Thereby, the presence of the yeast during refermentation can enhance 
storage stability and prolong beer shelf life [6]. Other types of microorganisms apart from brewing yeast can also be employed in bottle conditioning. In those cases, pronounced differences in the production of sensory-active metabolites in comparison with brewing yeast represent another source of distinctive features of the final beverage $[7,8]$.

\section{Historical Aspects of Bottle Conditioning}

Production of top-fermented beers prevailed until the second half of the 19th century. Due to the higher temperatures during fermentation, ales are typically less carbonated than bottom-fermented beers. Therefore, bottle conditioning was originally implemented as a method to enhance carbonation and thus eliminate the flat taste of beer [4]. The technology of introducing carbonation into a bottled beer beverage was inspired by the "champenoise" method for the production of sparkling wines, which has been known since the end of the 17th century and further established during the 18th century when glass bottles became widely available. Second alcoholic fermentation is one of the key steps after the first fermentation and blending of fermented grape juice from several varieties to achieve the desired balance of flavors. Sugar and yeast are added, and the blended mixture is introduced in thick-wall glass bottles and allowed to ferment at temperatures of $12-14{ }^{\circ} \mathrm{C}$. Second fermentation adds about $1.2-1.5 \%$ of ethanol and $11.8 \mathrm{~g} / \mathrm{L}$ of $\mathrm{CO}_{2}$. After a 15-month period of aging, bottles are disgorged, sediment of dead yeasts is removed, and a new cork stopper is used for closing [9]. As the "champenoise" method and its products had become increasingly popular, it was logical that brewers started to be interested to the implementation of those new technologies to increase the beer lifespan and attractiveness of their products.

Bottle conditioning has a long tradition in the production of Belgian acidic beers made by spontaneous mixed yeast bacterial fermentation. The biological principles of acidification were unveiled during the 18th century and acetic acid bacteria were identified at the end of the 19th century. The first bottled lambics were sold in 1844 . The term for beer made by blending of lambics and subsequently refermented in bottles is "Gueuze"; however, the origin of the name is unknown. Gueuze beers appeared in the market at the end of the 19th century. The maturation of lambic and Gueuze is assured by the presence of Brettanomyces sp. and their ability to cleave higher maltooligosaccharides. In Gueuze production, sugar or sugar and pure yeast suspension can be optionally added in bottles to support refermentation [10].

Traditionally, wort was being inoculated by yeast collected from the surface of a previous fermenting batch. In the Middle Ages, brewing was predominantly in hands of abbeys, which could assure stable production of grains and manage sustainable beer production [11]. In the 10th century, addition of hops was introduced in brewing to prevent beer turning sour and conserve it for further storage. The use of hops differed from region to region, but since the 14th century it was dominantly used in European countries, a trend that was confirmed by The Bavarian Beer Purity Law in 1516 [12-14]. Between the 15th and 16th centuries, Bavarian monks started with spontaneous selection of bottom-fermenting yeast by lagering of beer in cold cellars. As they observed, beer that was inoculated by yeast and settled to the bottom of the barrel after storage in the cellar had much better properties and stability [15]. This transition to cold fermentation was also supported by an edict of Prince Maximillian in 1533, which permitted brewing exclusively from September to April. The development of industrial refrigeration technology by von Linde has facilitated the production of bottom-fermented beers in larger manufacturing scales, regardless of the season. Nevertheless, many breweries were using natural ice cubes to cool their cellars until the first half of the 20th century. Furthermore, the construction of the thermometer and saccharometer enabled better control and understanding of the brewing process. The principle of alcoholic fermentation was elucidated by Gay-Lussac in 1810, who described the conversion of glucose to ethanol and carbon dioxide [16]. Carl Napoleon Balling defined the attenuation law in mathematical equations, which have been used until now $[17,18]$. Pasteur's discoveries from 1860s represent a historical milestone for the brewing industry. The role of microorganisms in beer spoilage and the approach on how to prevent it were explained in his work. Pasteur also introduced the technique of yeast acid washing to eliminate the presence of undesired contaminants during primary fermentation 
and described the differences of yeast aerobic and anaerobic metabolism. A few years later, in 1883, Hansen succeeded to isolate pure yeast strain and highlighted the importance of its use [16].

The evolution of bottle conditioning technology goes hand in hand with the development of packaging materials. Refermentation in wooden casks is the oldest method of conditioning applied for ale beers. Originally, the method has developed by ongoing fermentation of beer packed in the casks during transportation from breweries to pubs. As observed, beer obtained higher carbonation while on the way. The approach to beer conditioning evolved into a more sophisticated procedure; when following up primary fermentation, beer with a sufficient amount of residual extract and concentration of yeast cells around $0.1-1 \times 10^{6}$ per $\mathrm{mL}$ is racked into wooden casks and kept at lower temperatures $\left(12-14{ }^{\circ} \mathrm{C}\right)$ to be allowed to mature, which generates additional carbonation and drop of gravity $\left(1-2^{\circ} \mathrm{P}\right)$. The method is still used in the production of traditional English cask ale [19]. Even nowadays, cask-conditioned real ale is dispensed directly from the casks using hand pumps or gravity forces. In England, a voluntary organization, Campaign for Real Ale, was established in 1971 to promote this beer style and provide guidelines and supervision on the traditional technology of cask-conditioned beers [20]. The addition of fermenting wort containing yeast into beer during maturation stage or after racking is an established method for production of krausened lager in the Czech Republic. The presence of yeast contributes to beer freshness and imparts an authentic character [21,22].

The invention of crown corks and bottle openers in 1892 by Irish engineer William Painter brought up new possibilities and enabled consumption of beer in domestic conditions apart from pubs and bars [16]. The manufacturing of glass bottles became automatized by the end of the 19th century and was followed by gradual improvement of filling technologies during the 20th century. The generic use of wooden casks was progressively replaced by packaging into aluminum and stainless-steel kegs after the Second World War $[23,24]$. Dramatic development of industrial brewing technology during the 20th century resulted in improved quality of produced beers but also to unification and standardization of the major produced beer styles. Currently, emerging customer demand for innovative beer flavors related to the aspect of craft production introduces the urgency for product differentiation $[25,26]$. Bottle conditioning in bottles or casks can bring desired distinctiveness of brewers' portfolios.

\section{Principles of Flavor Enrichment by Bottle Conditioning}

Additional fermentation of beer in the final package induced by addition of yeast and sugars triggers multiple changes in its chemical and sensorial properties. Beer flavor is given by raw materials used for brewing and yeast metabolism during primary fermentation to a major extent. However, concentrations of flavor active compounds can be influenced throughout the full course of the production process and the final beer quality is a result of their mutual balance. When refermentation is applied, new flavors are additionally generated by the yeast activity in bottle or cask. Yeast metabolic products, which are the main constituents of beer aroma, are higher alcohols, esters, vicinal diketones, aldehydes, and sulfur compounds [27,28].

Higher alcohols can be synthesized de novo by anabolic pathways from carbohydrates or by the Ehrlich pathway as products of amino acid catabolism [29]. The most abundant in beer are n-propanol, iso-butanol, 2-methylbutanol, and 3-methylbutanol, contributing to the enhanced alcoholic flavor and promoting a warming character. In some beers, higher content of 2-phenylethanol is desirable, imparting its rose and floral aroma [30].

Esters are the contributors of floral, fruity, and solvent-like flavors and are present in trace concentrations. The most important flavor constituents with their respective flavors are ethyl acetate (green apple), isoamyl acetate (banana), ethyl butyrate (pineapple), ethyl hexanoate (sweet apple), isobutyl acetate (banana, sweet), ethyl caproate (apple, fruity), and 2-phenylethyl acteate (roses) [31]. Esters are formed by condensation of organic acid and alcohol. By yeast metabolism, two types of esters can be formed that comprise ethyl esters from condensation of ethanol and middle chain fatty acid or acetate esters formed from acetic acid and ethanol or higher alcohol [32]. 
Vicinal diketones (diacetyl and pentane-2,3-dione) are formed as intermediate products during synthesis of valine and isoleucine. Subsequently, they are reduced by yeast reductases during ongoing fermentation. Increased concentrations of vicinal diketones impart a buttery flavor and are therefore undesired [33].

Aldehydes are formed as intermediates during higher alcohol synthetic pathways. Furthermore, they are also formed during beer aging by oxidation of higher alcohols. Aldehydes have lower sensory thresholds compared to their respective alcohols. The most abundant, acetaldehyde, is associated with green apple flavor. Others confer with nutty, grainy, papery, and cardboard flavors, and are overall connected to a beer stale flavor [34].

Sulfur compounds occurring in beer comprise several groups of compounds with varied chemical structures (hydrogen sulfide and sulfur dioxide, thiols, sulfides, disulfides, trisulfides and thioesters). Most of them are derived from biosynthetic pathways of sulfur-containing amino acids methionine and cysteine, or from their successive degradation [35]. Hydrogen sulfide forms as a by-product that is subsequently added on allylic alcohols from hops or onto $\alpha, \beta$-unsaturated carbonyls from wort, forming sulfanylalkylalcohols (SA) or sulfanylalkylcarbonyls (SC), respectively. Examples of SA whose concentration increases during bottle conditioning are 3-sulfanylhexan-1-ol, imparting a rhubarb flavor, and 4-sulfanylnonan-2-ol, contributing a lemon flavor. Similarly, from the SC group, 4-sulfanyl-4-methylpentan-2-one and 3-sulfanylhexanal contribute catty and floral flavors [36]. Moreover, the concentration of free thiols during bottle conditioning is also increased due to yeast lyase activity, which cleaves present cysteine adducts [37]. The lyase activity is strain-dependent and can significantly vary in between different yeast strains [38]. Apart from sulfury notes given by the presence of inorganic sulfur compounds in beer, other sulfur-containing compounds are associated with undesired aromas resembling cabbage, corn, onion, or rotten vegetables [35].

During yeast growth phase, residual amino acids from beer are sequentially taken up and synthesis of aldehydes and higher alcohols proceeds. However, the extent of de novo formation of these compounds such as formation of esters in bottle-conditioned beer is much lower in comparison to main fermentation because of poor availability of metabolic substrates [4]. Despite that, even small changes in concentrations of flavor-active compounds can be perceivable, especially due to low thresholds of some of the esters [39].

Another pathway of new flavor formation during bottle conditioning is the release of flavor-active aglycones from their odorless glycoside-bound state by yeast enzymes with glucoside hydrolase activity, such as exo-1,3- $\beta$-glucanase (EC 3.2.1.58). The sources of these aromas are glycosides present in hops and malt, which are transferred into beer during the brewing process, with examples including citronellol, vanillin, and $\beta$-damascenone [40-42]. Some yeast strains are characteristic with pronounced formation of phenolic flavors, which resemble cloves, smoked meat, or medicinal odors. Due to the presence of the PAD1 gene, which encodes phenylacrylic acid decarboxylase, hydroxycinnamic acids ( $p$-coumaric acid and ferulic acid) can be decarboxylyzed to corresponding vinylphenols (4-vinylphenol and 4-vinylguaiacol, respectively), which are the carriers of the specific aroma typical mostly of wheat beers [43-45].

Changes in beer flavor during bottle conditioning can be additionally caused by mutual transformations of hop terpenoids induced by yeast enzymes [46]. As an example, citronellol is generated from geraniol, and linalool concentration can increase by transformation of nerol and geraniol, which leads to alterations of beer aroma [47].

Bottle conditioning leads to an increase of concentration of carbon dioxide, which supports beer effervescence. The major amount of $\mathrm{CO}_{2}$ in bottle-conditioned beer is generated by decarboxylation of pyruvate and formation of acetaldehyde by pyruvate decarboxylase. A certain amount of $\mathrm{CO}_{2}$ is also produced via the hexose monophosphate pathway and through the Krebs cycle [48].

When all fermentable sugars are metabolized and beer becomes saturated with $\mathrm{CO}_{2}$, yeast growth arrests and the cells enter the stationary phase. Progressively, the viability declines and the permeability of the yeast cell wall is disrupted, which causes autolyzes and release of intracellular content including hydrolytic enzymes, fatty acids, amino acids, peptides, and nucleotides, which can have a negative impact on the beer flavor, especially loss of fruity notes and occurrence flavors 
associated with beer aging [49,50]. Yeast esterases are also excreted into beer during main fermentation, and therefore it is sometimes advised to pasteurize beer prior to bottle conditioning to minimize ester degradation. The esterase activity is strain-dependent, and, generally, top-fermenting yeast possesses more active esterases than bottom-fermenting yeast. The most affected esters are isoamyl acetate, ethyl hexanoate, and ethyl octanoate, and the level of their cleavage depends on environmental conditions such as temperature, alcohol concentration, and $\mathrm{pH}[51,52]$. On the other hand, some esters are newly synthesized during storage, such as ethyl 2-methylbutyrate, ethyl nicotinate, and ethyl pyruvate [51]. They impart a winey aroma and are related to stale flavor [53].

Despite unfavorable conditions in beer in the beginning of bottle conditioning, which comprise the presence of alcohol and low $\mathrm{pH}$, yeast is still capable of multiplication and growth to some extent. Because the concentration of oxygen in final beer is limiting, fermentative metabolism is prevailing and only approximately $5 \%$ of added sugars are metabolized by respiratory pathway [4]. Dissolved oxygen and oxygen in the bottleneck space are also utilized for synthesis of fatty acids and sterols during yeast growth phase. Therefore, yeast is regarded as an oxygen scavenger in bottled beer, and since the role of oxygen in flavor deterioration of beer during storage is indisputable, the presence of yeast can exert protective effects and decelerate the beer aging process [54-56]. Fermentative metabolism generates reduced coenzymes NADH and NADPH, which are associated with yeast reducing power. These coenzymes are subsequently employed by several aldoketoreductases and convert aldehydes present in beer to their respective alcohols [57]. During the storage of packaged beer, several reactions comprising oxidation of fatty acids, Strecker degradation, and Maillard reactions occur spontaneously and give rise to carbonyl compounds that are considered as markers of aged flavor. Flavor stability has been extensively studied and, in particular, increased concentrations of linear aldehydes (trans-2-nonenal), Strecker aldehydes (2-methylpropanal, 2-methylbutanal, 3-methylbutanal, benzaldehyde, phenylacetaldehyde, methional), and furan derivatives (furfural, 5-hydroxymethylfurfural) are connected with undesired stale flavor $[34,58,59]$. Bottle conditioning can assure prolonged flavor stability by reducing the concentration of carbonyl compounds associated with staling, thereby diminishing the intensity of off flavors related to beer aging [60]. Furthermore, sulfites produced by yeast metabolism enhance flavor stability as well. The anti-aging mechanism of sulfites is exerted by radical scavenging, thus inhibiting the oxidative reactions; otherwise, they can bind to present aldehydes and form adducts with hydroxysulfonate structures [61].

Target flavor modification by bottle conditioning is considered as a type of bioflavoring and can be applied to generate distinctive flavors and produce beers with unique sensory profiles. Flavor modification is a result of multiple reactions and metabolic steps. The extent to which each type of reaction will manifest depends on a plethora of factors, including type of yeast strain, preparation of starter, amount of added sugar, temperature, and duration, as will be discussed in the next section.

\section{Conditioning Technology and Practices}

Multiple yeast and bacteria species are suitable for application in bottle conditioning, and several dosing strategies can be employed. Yeast can be added in the form of fermenting wort, harvested yeast from previous fermenting batch, or as a freshly propagated culture. In the case of harvested yeast, appropriate storage conditions must be assured to maintain viability and vitality. Using fermenting wort as a source of yeast for bottle conditioning can increase the risk of colloidal haze formation, which is related to the fact that wort is not stabilized prior to the addition into beer. Colloidal stability can be especially compromised in case higher amounts of wort has to be added due to lower cell concentrations [39]. Mixed cultures of various microorganisms can also be used, either obtained by spontaneous inoculation or by adding a selected mixture [62,63].

Selection of yeast strain is based on its different performance during bottle conditioning and depends on desired profile of the final product. Particular strains vary in the production of aromatic compounds and their alcohol tolerance. Usually, yeast strains characteristic with higher production of aromas tend to be more sensitive towards increased concentrations of ethanol $[62,64]$. 
Another option is use of dried yeast, which is suitable for cases when different strains are used for main fermentation and bottle conditioning [48,65-67]. Dried yeast was originally introduced in brewing as an alternative to the storage of pure yeast cultures [68]. Despite the traditional use of yeast in liquid forms prevailing, the use of dried yeast can also be beneficial, regardless the higher price and prolonged lag phase after pitching in comparison to standard liquid yeast [69]. Preference of yeast form used depends on the pitching regime of a particular brewery.

In general, microbreweries prefer dried yeast due to easy handling and lack of space for storage of harvested yeast. Meanwhile, large-scale breweries take advantage of using dried yeast for production of specialty beers and broadening their product portfolios. The decision between fresh or dried yeast relies on the amount of beer to be refermented as well as on the technological possibilities of the brewery. Refermentation yeast can be propagated in a separated propagation unit reserved for refermentation yeast only [64].

Dried brewing yeasts are widely commercially available from various producers. Its stability and shelf-life depend on manufacturing technology and storage conditions, including temperature and oxygen exposure [70,71].

Examples of yeast strain are Safbrew T-31, T-58, and S-33 from Fermentis, which are frequently used for bottle conditioning of Belgian top-fermented specialty beers [48].

Safbrew T-31 is resistant towards high alcohol concentration and has good sedimentation properties. Beers refermented by this strain are characterized by having a harsh taste and alcoholic aroma. T- 58 gives a balanced taste for a broad variety of beer types. On the contrary, Safbrew S-33 is a fast refermenting yeast, but the final beer properties are rather dependent on the beer type itself. Yeasts are not completely sedimented, and beer is characterized by high foam stability. Cultivation of yeast for bottle conditioning in media with the addition of sucrose is favorable for final beer characteristics, such as degree of attenuation, foam stability, sedimentation, and cell viability. These bottle refermentation characteristics are worse in beers refermented by yeast propagated on wort and harvested yeast [64].

Selection of yeast strain and the number of cells are crucial parameters that define the properties of final beer. The added amount depends on beer type and the desired degree of attenuation. By modification of refermentation dynamics, the flavor profile of beer can be adjusted. On the other hand, excessive carbonation can cause overfoaming [62]. Suitable cell concentration for pale beers with color below $12 \mathrm{EBC}$ and with alcohol content around $5 \mathrm{vol} \%$ is approximately 100,000 cells per mL. For stronger and darker beers (color above $35 \mathrm{EBC}$, alcohol higher than $7 \mathrm{vol} \%$ ), the yeast dose corresponds to 500,000 cells per milliliter [62]. Examples of yeast dosage for bottle conditioning in selected Belgian specialty beers are listed in Table 1, according to [72].

Table 1. Concentration of yeast cells for bottle conditioning in selected Belgian beers [72].

\begin{tabular}{cc}
\hline Beer & Yeast Cells (Million/mL) \\
\hline Duvel & 1 \\
Orval & 3 \\
Rochefort & 1 \\
Westmale & 2 \\
\hline
\end{tabular}

Modern production technology assures uptake of all fermentable sugars from wort; therefore, a source of sugars has to be added together with yeast to induce refermentation [62]. Sugars can be dosed in various forms, either crystalline with $100 \%$ purity or as syrups, which are $66 \%$ solutions containing $25-90 \%$ of fermentable sugars. [73]. Sugar syrups are prepared by dissolution at increased temperatures or in ambient conditions. In syrups made by cold approach, the risk of microbial contamination has to be eliminated by additional sterilization [62]. 
The amount of sugar ( $\mathrm{g}$ ) added into beer in a form of suspension with yeast cells (A) can be calculated according to Equation (1):

$$
A=2 B-(0.3 C+D)
$$

Sugar amount is related to desired amount of $\mathrm{CO}_{2}$ in grams (B), amount and type of residual fermentable sugar in grams (C) (e.g., coefficient for maltotriose is 0 ), and the content of $\mathrm{CO}_{2}(\mathrm{~g})$ in beer prior to refermentation (D). $\mathrm{CO}_{2}$ content in beer after fermentation in an open vessel at $20{ }^{\circ} \mathrm{C}$ is approximately $1.5 \mathrm{~g} / \mathrm{L}$, but in cased of fermentation at an overpressure of $100 \mathrm{kPa}$, carbonation is around $4.4 \mathrm{~g} / \mathrm{L}$.

Target $\mathrm{CO}_{2}$ in bottle-conditioned beer is within the range of $5-8 \mathrm{~g} / \mathrm{L}$, but even beers with $9 \mathrm{~g} / \mathrm{L} \mathrm{CO}$ can be found. In $\mathrm{CO}_{2}$ lower than the desired range, beer will taste flat, and on the other hand, higher carbonation is associated with an increased risk of overfoaming, especially at increased temperatures [62].

Increased content of $\mathrm{CO}_{2}$ requires increased pressure resistance of bottles and closures. As an example, from winemaking, packaging materials for sparkling wine production can withstand pressure higher than 12 bars, which corresponds to carbonation of $12 \mathrm{~g} / \mathrm{L}$ that is achieved by refermentation in bottle [74-76].

Packaging materials for bottle conditioning include all the types commonly used for beer. Additional precautions should be taken when flexible materials, such as cans and plastic bottles, are used, in order to eliminate any risks of bursting or swelling of the containers. A bunging valve can be used for regulation of pressure inside a stainless-steel keg.

Optimal temperature for bottle conditioning is dependent on the selected yeast strain and, most frequently, recommended temperatures are within the range of $14-22{ }^{\circ} \mathrm{C}$ [62]. Practical examples of bottle conditioning procedures and successive operations are visualized in Figure 1. Each brewery follows its own adapted practices dependent on the technological options and available equipment [72].

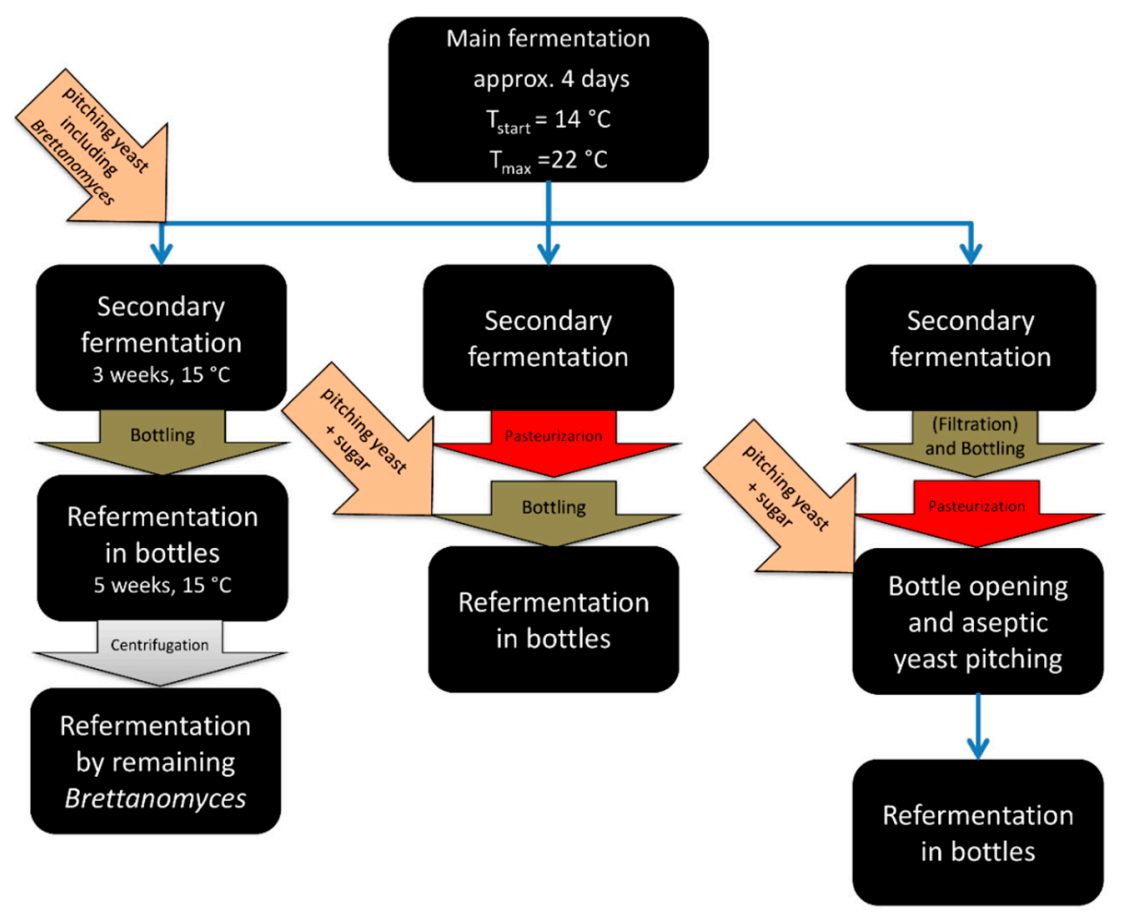

Figure 1. Practical approaches for production of bottle-conditioned beers.

The course of bottle conditioning can be controlled by several analytical features, including content of $\mathrm{CO}_{2}$, changes of density, extract content, concentration of yeast, and its viability. Monitoring of turbidity and the amount of yeast sediment also serve as important indicators of the process [64]. 


\section{Bottle Conditioning in the Presence of Mixed Microbial Cultures}

Using other microorganisms apart from brewing yeast during beer conditioning brings an even broader diversity into beer flavor profile. Mixed yeast bacterial conditioning has a long tradition in some specialty beer types such as sour ales (Belgian red ale, Belgian brown ale, Berliner Weisse), lambics, and geuze or American coolship ale. An additional fermentation phase occurs during maturation in wooden casks or is triggered by final blending of different batches [77].

Flavor enhancement by non-Saccharomyces microorganisms is a result of different metabolic pathways in comparison to brewing yeast, which lead to the synthesis of atypical sensory-active compounds. Non-Saccharomyces yeast species most frequently involved in spontaneously fermented beer styles embrace Brettanomyces (Dekkera) spp., Lachancea thermotolerans, Candida spp., Torulopsis spp., Cryoptococcus spp., Kloeckera spp., Pichia spp., and Rhodotorula spp. [39]. The most relevant features of their metabolism include regulation of sugar catabolism; oxygen requirements; and specific metabolism of nitrogen, phosphorus, and activity of particular enzymes that give rise to flavor-active secondary metabolites upon the environment in beer during conditioning. Whereas in Saccharomyces, Crabtree and Pasteur effects are observed, other yeast species, such as Brettanomyces (or its teleomorph Dekkera) or Candida sp. are typically Crabtree- and Pasteur-negative. Pasteur-negative, lately denoted as the Custers effect, is characterized by inability to ferment glucose to ethanol in anaerobic conditions. Brettanomyces is distinctive for its formation of acetic acid by $\mathrm{NAD}^{+}$-aldehyde dehydrogenase, which generates excessive amount NADH that cannot be converted back to NAD in the absence of oxygen as an electron acceptor and the redox balance cannot be further maintained, which leads to glycolysis arrest [78].

Therefore, Brettanomyces is suitable for conditioning of beer in wooden casks, where the desired microaerophilic conditions are achieved due to the porous character of wooden walls [79]. Strictly aerobic species that can occur during conditioning of spontaneously fermented beers include Candida utilis anomala, Pichia fermentans, and Torulopsis sake [39]. Methylotrophic yeasts such as Candida methanolovescens possess alcohol oxidase, which is employed in oxidation of methanol to formaldehyde. When applied in beer conditioning, alcohol oxidase converts alcohols present in beer to their respective aldehydes, which can cause increase of fruity and flowery flavors, depending on the length of the carbonyl chain [80]. In other yeast species, e.g., Pichia spp., Rhodotorula spp. or Torulopsis spp., linear long-chain alcohols can be additionally converted to aldehydes by $\mathrm{NAD}^{+}$-linked long-chain alcohol dehydrogenase [81].

Non-Saccharomyces yeast are also capable to cleave glycosides by the action of $\beta$-glucosidase and contribute to the aroma enhancement by released aglycones. This approach can be especially applied in dry-hopped beers or in beers where fruits, spices, hops, or wooden pellets were added as sources of additional flavors [40]. In Brettanomyces, esterases are responsible for hydrolysis of acetate esters, such as isoamyl acetate and phenylethyl acetate, and cause the formation of ethyl esters including ethyl lactate or ethyl acetate, ethyl caprylate, and ethyl caprate. Brettanomyces are also associated with the production of mousy off-flavors, which are related to the formation of substituted tetrahydropyridines [78]. Due to the presence of $\alpha$-glucosidase, Brettanomyces is capable of utilizing dextrins, which is a cause of higher attenuation of lambic or other beers where Brettanomyces were employed [82,83]. Furthermore, other non-Saccharomyces produce extracellular $\alpha$-amylases, or they can also degrade hemicellulose and pectin by xylanase or polygalacturonase, respectively [84]. Brettanomyces spp. and some strains of Pichia guilliermondii, as well as some lactic acid bacteria (Lactobacillus plantarum), produce volatile phenolic compounds that represent some of the most perceptible parts of the final beer aroma [44]. The synthesis is enabled due to the presence of phenylacrylic acid decarboxylase and, additionally, in Brettanomyces, also by vinylphenol reductase, converting vinylphenol derivatives into their ethylphenolic analogues with lower sensory thresholds. Phenolic compounds are altogether characteristic by medicinal, clove-like, and spicy aromas [45].

The production of German-style wheat beer is connected with mixed cultures of Saccharomyces cerevisiae and Torulaspora delbrueckii [85]. Torulaspora imparts a distinctive fruity aroma due to the increased production of esters, higher alcohols, and phenolic compounds, and its application for mixed culture refermentations has been assessed [86]. Due to the slower uptake of maltose, it has also been 
examined for the application in low-alcoholic beer production. Torulaspora also occurs in traditional African "pito" sorghum beers, which are fermented by spontaneously inoculated microflora [87].

With the increasing popularity of sour beers, lactic acid bacteria are frequently employed to achieve innovative flavor complexity and optimal sour taste [88]. Despite the method of "kettle souring" that is prevailing in sour beer production, during which the wort is pitched by lactic acid bacteria (LAB) while still placed in wort kettle and then boiled again to interrupt the acidification, LAB can also be present in primary fermentation in the form of mixed culture or introduced for refermentation during maturation phase [89]. This approach is followed in the traditional production of Berliner Weisse. Cooled wort is pitched by a mixture of brewing yeast and LAB in the ratios between 4:1 and $6: 1$, and the main fermentation takes approximately 4 days. Before bottling, the so-called kräusen is added into the green beer to provoke additional fermentation in the bottle. Kräusen in Berliner Weisse production is a term for the layer of yeast collected from the top of fermenting beer during main fermentation [90]. LAB are non-respiring facultative anaerobes and lactic acid represents a dominating end-product of their carbohydrate metabolism.

As an alternative, use of Lachancea thermotolerans, which produces lactic acid, has been suggested for sour beermaking [91]. However, the acidifying effect during refermentation has not been observed in comparison to beer conditioned by brewing yeast [92].

In the case of Belgian lambic and Gueuze, wort is spontaneously inoculated by microorganisms present in the brewery ambient air during overnight cooling. Usually, fermentation consists of several stages where a group of particular microorganisms prevails. Fermentation is initiated by Enterobacteriaceae lasting for a month, followed by Saccharomyces stage, where S. cerevisiae and Saccharomyces pastorianus prevail. After approximately 4 months, the acidification by LAB (Pediococci and Lactobacilli), acetic acid bacteria, and Brettanomyces takes place. During further maturation, bacterial and yeast counts progressively decline $[93,94]$. In Gueuze, the final stage of bottle conditioning is induced by blending of lambics aged for different periods of time prior to bottling. During this stage, significant variations of the present microbiota between individual bottles were identified. Upon aging, the concentration of lactic acid and ethyl-lactate increases, while isoamyl acetate decreases. Therefore, it was suggested that the optimal duration of Gueuze aging should not exceed 10 years [95].

Similarly, fermentation of red and brown acidic ale produced in the Flanders region in Belgium can also be described as a tandem process [96]. After the first stage, Saccharomyces are overlapped by LAB-producing lactic acid. Successively, beer matures in oak barrels or in stainless-steel vessels for up to 24 months, and the prevailing microbiota are Brettanomyces, Peddiococci, and acetic acid bacteria. The final beer is blended from the mature beer and young beer from the stage prior to barrel maturation. The most import flavor constituents are identified in the end product are lactic acid, ethyl acetate, isoamyl acetate, ethyl hexanoate, and ethyl octanoate [97].

\section{Conclusions}

The inspiring idea of bottle conditioning came into the brewing industry from winemaking in the middle of the 19th century. Since then, it has been established as a traditional method for production of specialty beers, particularly in Belgium, as well as for other specific beer types in selected European regions. Nowadays, the old traditions are being reborn and innovated worldwide, following current trends in craft brewing. In our review, we demonstrated the principles and technological aspects of bottle conditioning. Furthermore, we explained how it contributes to flavor complexity and assures exclusivity of the product. Bottle conditioning can represent an opportunity for the enrichment of brewers' portfolios and, simultaneously, it can be an approach as to how to satisfy growing customer demand for beers with distinctive character.

Author Contributions: Conceptualization, K.Š. and J.N.; writing-original draft preparation, K.Š. and J.V.; writing-review and editing, J.N., J.Š., and P.K.; visualization, J.V.; supervision, J.N., P.K., and P.D. All authors have read and agreed to the published version of the manuscript. 
Funding: This research received no external funding.

Conflicts of Interest: The authors declare no conflict of interest.

\section{References}

1. Garavaglia, C.; Swinnen, J. Economics of the craft beer revolution: A comparative international perspective. In Economic Perspectives on Craft Beer, 1st ed.; Garavaglia, C., Swinnen, J., Eds.; Springer: New York, NY, USA, 2018; pp. 3-51.

2. Elzinga, K.G.; Tremblay, C.H.; Tremblay, V.J. Craft beer in the United States: History, numbers, and geography. J. Wine Econ. 2015, 10, 242. [CrossRef]

3. Aquilani, B.; Laureti, T.; Poponi, S.; Secondi, L. Beer choice and consumption determinants when craft beers are tasted: An exploratory study of consumer preferences. Food Qual. Prefer. 2015, 41, 214-224. [CrossRef]

4. Daenen, L.; Saison, D.; De Schutter, D.; De Cooman, L.; Verstrepen, K.; Delvaux, F.; Derdelinckx, G.; Verachtert, H. Bioflavoring of beer through fermentation, refermentation and plant parts addition. In Beer in Health and Disease Prevention; Preedy, V., Ed.; Elsevier: Amsterdam, The Netherlands, 2009; pp. 33-49.

5. Derdelinckx, G.; Neven, H.; Arnott, P.; Demeyer, I.; Delvaux, F. Belgian special beers: Refermented beers; white and wheat beers; amber and dark beers; spiced and hoppy beers. Cerevisia Biotechnol. 1995, 20, 67-73.

6. Saison, D.; De Schutter, D.P.; Delvaux, F.; Delvaux, F.R. Improved flavor stability by aging beer in the presence of yeast. J. Am. Soc. Brew. Chem. 2011, 69, 50-56. [CrossRef]

7. Gutiérrez, A.; Boekhout, T.; Gojkovic, Z.; Katz, M. Evaluation of non-Saccharomyces yeasts in the fermentation of wine, beer and cider for the development of new beverages. J. Inst. Brew. 2018, 124, 389-402. [CrossRef]

8. Berlowska, J.; Kregiel, D.; Rajkowska, K. Biodiversity of brewery yeast strains and their fermentative activities. Yeast 2015, 32, 289-300. [CrossRef]

9. Liger-Belair, G. Wines: Champagne and sparkling wines-production and effervescence. In Encyclopedia of Food and Health, 1st ed.; Caballero, B., Finglas, P., Toldra, F., Eds.; Elsevier: Amsterdam, The Netherlands, 2016; pp. 526-533.

10. Verachtert, H.; Derdelinckx, G. Belgian acidic beers: Daily reminiscences of the past. Cerevisia 2014, 38, 121-128. [CrossRef]

11. Nelson, M. Celtic and Egyptian beer-production traditions and the origins of Western European monastic brewing. J. Mediev. Monast. Stud. 2018, 7, 47-77. [CrossRef]

12. Moir, M. Hops-A millennium review. J. Am. Soc. Brew. Chem. 2000, 58, 131-146. [CrossRef]

13. Biendl, M.; Pinzl, C. Hops and health. MBAA TQ 2009, 46, 1-7. [CrossRef]

14. DeLyser, D.Y.; Kasper, W.J. Hopped beer: The case for cultivation. Econ. Bot. 1994, 48, 166-170. [CrossRef]

15. Wayens, B.; Van den Steen, I.; Ronveaux, M.-E. A short historical geography of beer. In Food and Environment: Geographies of Taste, 1st ed.; Montanari, A., Ed.; Società Geografica Italiana: Rome, Italy, 2002; pp. 93-114.

16. Bamforth, C.W. BEERS|History and Types. In Encyclopedia of Food Sciences and Nutrition, 2nd ed.; Caballero, B., Trugo, L., Finglas, P., Eds.; Academic Press: London, UK, 2003; pp. 418-422.

17. Basařová, G. Profesor pražské techniky Carl Joseph Napoleon Balling (1805-1868). Kvas. Prum 2005, 51, 130-135. [CrossRef]

18. Šavel, J.; Košin, P.; Brož, A. Balling alcohol factors from the perspective of contemporary brewing. Kvas. Prum 2015, 61, 120-128. [CrossRef]

19. Pavsler, A.; Buiatti, S. Non-lager Beer. In Beer in Health and Disease Prevention; Preedy, V., Ed.; Elsevier: Amsterdam, The Netherlands, 2019; p. 20.

20. CAMRA's Definition of Real Ale. Available online: https://s3-eu-west-1.amazonaws.com/www1-camra/wpcontent/uploads/2019/04/14103840/CAMRA-Definition-of-Real-Ale-v.May2018.pdf (accessed on 6 June 2020).

21. Basařová, G.; Šavel, J.; Basař, P.; Lejsek, T. Fermentation and Lagering. In Brewing, Theory and Practice of Beer Production, 1st ed.; VŠCHT Praha: Prague, Czech Republic, 2010; p. 385.

22. Budvar Kroužek. Available online: https://www.budejovickybudvar.cz/sortiment/budvar-krouzek-3 (accessed on 25 July 2020).

23. Twede, D. The cask age: The technology and history of wooden barrels. Packag. Technol. Sci. 2005, 18, $253-264$. [CrossRef]

24. Lowe, C.; Elkin, W. Beer packaging in glass and recent developments. J. Inst. Brew. 1986, 92, 517-528. [CrossRef] 
25. Chapman, N.G.; Lellock, J.S.; Lippard, C.D. Untapped: Exploring the Cultural Dimensions of Craft Beer; West Virginia University Press: Morgantown, WV, USA, 2017.

26. Berning, J.; McCullough, M. Product line extension among New England craft breweries. Agric. Econ. Res. Rev. 2017, 46, 73-86. [CrossRef]

27. Pires, E.J.; Teixeira, J.A.; Brányik, T.; Vicente, A.A. Yeast: The soul of beer's aroma-A review of flavour-active esters and higher alcohols produced by the brewing yeast. Appl. Microbiol. Biotechnol. 2014, 98, 1937-1949. [CrossRef]

28. Guido, L.; Rajendram, R.; Barros, A.A. Pitching Yeast and Beer Flavour. In Beer in Health and Disease Prevention; Preedy, V., Ed.; Elsevier: Amsterdam, The Netherlands, 2009; pp. 23-32.

29. Hazelwood, L.A.; Daran, J.-M.; Van Maris, A.J.; Pronk, J.T.; Dickinson, J.R. The Ehrlich pathway for fusel alcohol production: A century of research on Saccharomyces cerevisiae metabolism. Appl. Environ. Microbiol. 2008, 74, 2259-2266. [CrossRef]

30. Stewart, G.G. The production of secondary metabolites with flavour potential during brewing and distilling wort fermentations. Fermentation 2017, 3, 63. [CrossRef]

31. Meilgaard, M.C. Individual differences in sensory threshold for aroma chemicals added to beer. Food Qual. Prefer. 1993, 4, 153-167. [CrossRef]

32. Saison, D.; De Schutter, D.P.; Vanbeneden, N.; Daenen, L.; Delvaux, F.; Delvaux, F.R. Decrease of aged beer aroma by the reducing activity of brewing yeast. J. Agric. Food Chem. 2010, 58, 3107-3115. [CrossRef] [PubMed]

33. Bamforth, C.; Kanauchi, M. Enzymology of vicinal diketone reduction in brewer's yeast. J. Inst. Brew. 2004, 110, 83-93. [CrossRef]

34. Vanderhaegen, B.; Neven, H.; Verachtert, H.; Derdelinckx, G. The chemistry of beer aging-A critical review. Food Chem. 2006, 95, 357-381. [CrossRef]

35. Boulton, C.; Quain, D. Brewing Yeasts and Fermentation; Blackwell: Oxford, UK, 2006; pp. 113-141.

36. Nizet, S.; Gros, J.; Peeters, F.; Chaumont, S.; Robiette, R.; Collin, S. First evidence of the production of odorant polyfunctional thiols by bottle refermentation. J. Am. Soc. Brew. Chem. 2013, 71, 15-22. [CrossRef]

37. Nizet, S.; Peeters, F.; Gros, J.; Collin, S. Odorant polyfunctional thiols issued from bottle beer refermentation. In Flavour Science; Elsevier: Amsterdam, The Netherlands, 2014; pp. 227-230.

38. Belda, I.; Ruiz, J.; Navascués, E.; Marquina, D.; Santos, A. Improvement of aromatic thiol release through the selection of yeasts with increased $\beta$-lyase activity. Int. J. Food Microbiol. 2016, 225, 1-8. [CrossRef] [PubMed]

39. Vanderhaegen, B.; Coghe, S.; Vanbeneden, N.; Van Landschoot, A.; Vanderhasselt, B. Yeasts as postfermentation agents in beer. Mon. Brauwiss. 2002, 55, 218-232.

40. Daenen, L.; Saison, D.; De Cooman, L.; Derdelinckx, G.; Verachtert, H.; Delvaux, F. Flavour enhancement in beer: Hydrolysis of hop glycosides by yeast beta-glucosidase. Cerevisia 2007, 32, 24-36.

41. Jin, H.; Rogers, P. Novel recovery of malt flavours from their glycosidically bound precursors. TQ MBAA 2000, 37, 79-83.

42. Ferreira, C.S.; Bodart, E.; Collin, S. Why craft brewers should be advised to use bottle refermentation to improve late-hopped beer stability. Beverages 2019, 5, 39. [CrossRef]

43. Coghe, S.; Benoot, K.; Delvaux, F.; Vanderhaegen, B.; Delvaux, F.R. Ferulic acid release and 4-vinylguaiacol formation during brewing and fermentation: Indications for feruloyl esterase activity in Saccharomyces cerevisiae. J. Agric. Food. Chem. 2004, 52, 602-608. [CrossRef]

44. Lentz, M. The impact of simple phenolic compounds on beer aroma and flavor. Fermentation 2018, 4, 20. [CrossRef]

45. Vanbeneden, N.; Gils, F.; Delvaux, F.; Delvaux, F.R. Formation of 4-vinyl and 4-ethyl derivatives from hydroxycinnamic acids: Occurrence of volatile phenolic flavour compounds in beer and distribution of Pad1-activity among brewing yeasts. Food Chem. 2008, 107, 221-230. [CrossRef]

46. King, A.J.; Dickinson, J.R. Biotransformation of hop aroma terpenoids by ale and lager yeasts. FEMS Yeast Res. 2003, 3, 53-62. [CrossRef]

47. Praet, T.; Van Opstaele, F.; Jaskula-Goiris, B.; Aerts, G.; De Cooman, L. Biotransformations of hop-derived aroma compounds by Saccharomyces cerevisiae upon fermentation. Cerevisia 2012, 36, 125-132. [CrossRef]

48. Vanderhaegen, B.; Neven, H.; Coghe, S.; Verstrepen, K.; Derdelinckx, G.; Verachtert, H. Bioflavoring and beer refermentation. Appl. Microbiol. Biotechnol. 2003, 62, 140-150. [CrossRef] [PubMed] 
49. Ormrod, I.; Lalor, E.; Sharpe, F. The release of yeast proteolytic enzymes into beer. J. Inst. Brew. 1991, 97, 441-443. [CrossRef]

50. Chen, E.C.-H.; Jamieson, A.; Van Gheluwe, G. The release of fatty acids as a consequence of yeast autolysis. J. Am. Soc. Brew. Chem. 1980, 38, 13-18. [CrossRef]

51. Neven, H.; Delvaux, F.; Derdelinckx, G. Flavor evolution of top fermented beers. TQ MBAA 1997, 34, 115-118.

52. Vesely, P.; Volgyi, A.; Lusk, L.T.; Basarova, G.; Navarro, A. Impact of esterase activity in aseptically packaged, unpasteurized beer. TQ MBAA 2004, 41, 293-297.

53. Lehnhardt, F.; Gastl, M.; Becker, T. Forced into aging: Analytical prediction of the flavor-stability of lager beer. A review. Crit. Rev. Food Sci. Nutr. 2004, 59, 2642-2653. [CrossRef]

54. Kreim, J.; Stumpf, L.; Dobrick, S.; Hinrichs, J.; Pahl, R.; Brauer, J.; Schildbach, S. Enhancing flavour stability in beer using biological scavengers part 1: Methodology and preliminary trials. Mon. Brauwiss. 2018, 71, 12.

55. Kuchel, L.; Brody, A.L.; Wicker, L. Oxygen and its reactions in beer. Packag. Technol. Sci. 2006, 19, 25-32. [CrossRef]

56. Bamforth, C.W.; Muller, R.; Walker, M. Oxygen and oxygen radicals in malting and brewing: A review. J. Am. Soc. Brew. Chem. 1993, 51, 79-88. [CrossRef]

57. Ahrens, H.; Schröpfer, J.; Stumpf, L.; Pahl, R.; Brauer, J.; Schildbach, S. Enhancing flavour stability in beer using biological scavengers part 2: Screening of yeasts. Mon. Brauwiss. 2018, 71, 24.

58. Saison, D.; Vanbeneden, N.; De Schutter, D.; Daenen, L.; Mertens, T.; Delvaux, F.; Delvaux, F. Characterisation of the flavour and the chemical composition of lager beer after ageing in varying conditions. Brew. Sci. 2010, 63, 41-53.

59. Wietstock, P.C.; Kunz, T.; Methner, F.J. Relevance of oxygen for the formation of Strecker aldehydes during beer production and storage. J. Agric. Food Chem. 2016, 64, 8035-8044. [CrossRef]

60. Bamforth, C.W. 125th Anniversary Review: The non-biological instability of beer. J. Inst. Brew. 2011, 117, 488-497. [CrossRef]

61. Baert, J.J.; De Clippeleer, J.; Hughes, P.S.; De Cooman, L.; Aerts, G. On the origin of free and bound staling aldehydes in beer. J. Agric. Food Chem. 2012, 60, 11449-11472. [CrossRef]

62. Derdelinckx, G.; Vanderhasselt, B.; Maudoux, M.; Dufour, J. Refermentation in bottles and kegs. A rigorous approach. Brauwelt Int. 1992, 2, 156-164.

63. Verachtert, H.; Iserentant, D. Properties of Belgian acid beers and their microflora. The production of Gueuze and related refreshing acid beers. Cerevisia 1995, 20,37-41.

64. Van Landschoot, A.; Vanbeneden, N.; Vanderputten, D.; Derdelinckx, G. Effect of pitching yeast preparation on the refermentation of beer in bottles. Cerevisia 2004, 29, 140-146.

65. Fels, S.; Reckelbus, B.; Gosselin, Y. Dried yeasts-A truly multifunctional product [for brewing]. Cerevisia 1999, 24, 17-20.

66. Reckelbus, B.; Fels, S.; Gosselin, Y.; Debourg, A. Optimising the use of dried yeasts in breweries. TQ MBAA 2000, 37, 21-25.

67. Muller, R.; Fels, S.; Gosselin, Y. Brewery fermentations with dried lager yeast. In Proceedings of the European Brewery Convention - the 26th Congress, Maastricht, The Netherlands, 1 January 1997; Van Wijngaarden, M., Ed.; Oxford University Press: Oxford, UK, 1998; pp. 431-438.

68. Guldfeldt, L.; Piper, J. Yeast typing and propagation of dry brewing yeast cultures. TQ MBAA 1999, 36, 1-6.

69. Spearot, J. Microscale and macroscale effect of the early pitching method on beer composition during the brewing process. TQ MBAA 2014, 51, 97-105. [CrossRef]

70. Bayrock, D.; Ingledew, W. Mechanism of viability loss during fluidized bed drying of baker's yeast. Food Res. Int. 1997, 30, 417-425. [CrossRef]

71. Yüzgeç, U.; Türker, M. Comparison of different modeling concepts for drying process of baker's yeast. IFAC Proc. Vol. 2009, 42, 816-821. [CrossRef]

72. Hieronymus, S. Brew Like a Monk: Trappist, Abbey and Strong Belgian Ales and How to Brew Them; Brewers Publications: Boulder, CO, USA, 2005.

73. Vanbeneden, N.; Vanderputten, D.; Vanderhaegen, B.; Derdelinckx, G.; Van Landschoot, A. Influence of the sugar composition of the added extract on the refermentation of beer in bottles. J. Am. Soc. Brew. Chem. 2006, 64, 206-213. [CrossRef]

74. Liger-Belair, G. Uncorked: The Science of Champagne; Princeton University Press: Princeton, NJ, USA, 2013; pp. 37-58. 
75. Liger-Belair, G. Effervescence in Champagne and sparkling wines: From grape harvest to bubble rise. Eur. Phys. J. Spec. Top. 2017, 226, 3-116. [CrossRef]

76. Kemp, B.; Alexandre, H.; Robillard, B.; Marchal, R. Effect of production phase on bottle-fermented sparkling wine quality. J. Agric. Food Chem. 2015, 63, 19-38. [CrossRef]

77. Dysvik, A.; La Rosa, S.L.; De Rouck, G.; Rukke, E.-O.; Westereng, B.; Wicklund, T. Microbial dynamics in traditional and modern sour beer production. Appl. Environ. Microbiol. 2020, 86, e00566-20. [CrossRef] [PubMed]

78. Steensels, J.; Daenen, L.; Malcorps, P.; Derdelinckx, G.; Verachtert, H.; Verstrepen, K.J. Brettanomyces yeasts-From spoilage organisms to valuable contributors to industrial fermentations. Int. J. Food Microbiol. 2015, 206, 24-38. [CrossRef] [PubMed]

79. De Roos, J.; Van der Veken, D.; De Vuyst, L. The interior surfaces of wooden barrels are an additional microbial inoculation source for lambic beer production. Appl. Environ. Microbiol. 2019, 85, e2226-18. [CrossRef] [PubMed]

80. Nozaki, M.; Suzuki, N.; Washizu, Y. Microbial oxidation of alcohols by Candida boidinii: Selective oxidation. In ACS Symposium Series. Biotechnology for Improved Foods and Flavors; Takeoka, G.R., Teranishi, R., Williams, P., Kobayashi, A., Eds.; American Chemical Society: Washington, DC, USA, 1996; Volume 637, pp. 188-195.

81. Cartledge, T.G. Substrate utilization, non-carbohydrate substrates. In Yeast Biotechnology; Berry, D., Russel, I., Stewart, G., Eds.; Allen and Unwin: London, UK, 1987; pp. 311-342.

82. Steensels, J.; Verstrepen, K.J. Taming wild yeast: Potential of conventional and nonconventional yeasts in industrial fermentations. Annu. Rev. Microbiol. 2014, 68, 61-80. [CrossRef]

83. Spitaels, F.; Wieme, A.D.; Snauwaert, I.; De Vuyst, L.; Vandamme, P. Microbial ecology of traditional beer fermentations. In Brewing Microbiology: Current Research, Omics and Microbial Ecology; Bokulich, N., Bamforth, C., Eds.; Caister Academic Press: Poole, UK, 2017; pp. 179-196.

84. Walker, G.M. Yeast metabolism. In Yeast Physiology and Biotechnology; John Wiley \& Sons: Chicheter, UK, 1998; p. 229.

85. Tataridis, P.; Kanelis, A.; Logotetis, S.; Nerancis, E. Use of non-Saccharomyces Torulaspora delbrueckii yeast strains in winemaking and brewing. Zb. Matice Srp. Prir. Nauk. 2013, 415-426. [CrossRef]

86. Canonico, L.; Comitini, F.; Ciani, M. Torulaspora delbrueckii contribution in mixed brewing fermentations with different Saccharomyces cerevisiae strains. Int. J. Food Microbiol. 2017, 259, 7-13. [CrossRef] [PubMed]

87. Jespersen, L. Occurrence and taxonomic characteristics of strains of Saccharomyces cerevisiae predominant in African indigenous fermented foods and beverages. FEMS Yeast Res. 2003, 3, 191-200. [CrossRef]

88. Tonsmeire, M. American Sour Beer: Innovative Techniques for Mixed Fermentations; Brewers Publications: Boulder, CO, USA, 2014.

89. Peyer, L.C.; Zarnkow, M.; Jacob, F.; De Schutter, D.P.; Arendt, E.K. Sour brewing: Impact of Lactobacillus Amylovorus Fst2. 11 on technological and quality attributes of acid beers. J. Am. Soc. Brew. Chem. 2017, 75, 207-216. [CrossRef]

90. Bossaert, S.; Crauwels, S.; De Rouck, G.; Lievens, B. The power of sour-A review: Old traditions, new opportunities. Brew. Sci. 2019, 72, 78-88.

91. Domizio, P.; House, J.; Joseph, C.; Bisson, L.; Bamforth, C. Lachancea thermotolerans as an alternative yeast for the production of beer. J. Inst. Brew. 2016, 122, 599-604. [CrossRef]

92. Callejo, M.; Navas, J.G.; Alba, R.; Escott, C.; Loira, I.; González, M.; Morata, A. Wort fermentation and beer conditioning with selected non-Saccharomyces yeasts in craft beers. Eur. Food Res. Technol. 2019, 245, 1229-1238. [CrossRef]

93. Spitaels, F.; Wieme, A.D.; Janssens, M.; Aerts, M.; Van Landschoot, A.; De Vuyst, L.; Vandamme, P. The microbial diversity of an industrially produced lambic beer shares members of a traditionally produced one and reveals a core microbiota for lambic beer fermentation. Food Microbiol. 2015, 49, 23-32. [CrossRef]

94. De Roos, J.; Vandamme, P.; De Vuyst, L. Wort substrate consumption and metabolite production during lambic beer fermentation and maturation explain the successive growth of specific bacterial and yeast species. Front. Microbiol. 2018, 9, 2763. [CrossRef] [PubMed]

95. Spitaels, F.; Van Kerrebroeck, S.; Wieme, A.D.; Snauwaert, I.; Aerts, M.; Van Landschoot, A.; De Vuyst, L.; Vandamme, P. Microbiota and metabolites of aged bottled gueuze beers converge to the same composition. Food Microbiol. 2015, 47, 1-11. [CrossRef] [PubMed] 
96. Martens, H.; Iserentant, D.; Verachtert, H. Microbiological aspects of a mixed yeast-Bacterial fermentation in the production of a special Belgian acidic ale. J. Inst. Brew. 1997, 103, 85-91. [CrossRef]

97. Snauwaert, I.; Roels, S.P.; Van Nieuwerburgh, F.; Van Landschoot, A.; De Vuyst, L.; Vandamme, P. Microbial diversity and metabolite composition of Belgian red-brown acidic ales. Int. J. Food Microbiol. 2016, 221, 1-11. [CrossRef] [PubMed]

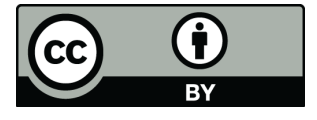

(C) 2020 by the authors. Licensee MDPI, Basel, Switzerland. This article is an open access article distributed under the terms and conditions of the Creative Commons Attribution (CC BY) license (http://creativecommons.org/licenses/by/4.0/). 